\title{
Using Phragmites australis(Iraqi plant) to remove the Lead (II) Ions form Aqueous solution.
}

\author{
Khulood A. S. Al-Saade \\ Dunya Edan AL-Mammar \\ Huda N. AL-Ani \\ Department of Chemistry, College of Science, University of Baghdad, Jadiriya, \\ Baghdad, Iraq \\ E-mail: hudanajim2005@yahoo.com
}

Received 5/11/2015

Accepted 19/7/2016

(c) $(1) \Theta(\Theta$

Derivatives 4.0 International License

\begin{abstract}
:
Lead remediation was achieved using simple cost, effective and eco-friendly way from industrial wastewater. Phragmitesaustralis (P.a) (Iraqi plant), was used as anovel biomaterial to remove lead ions from synthesized waste water. Different parameters which affected on adsorption processes were investigated like adsorbent dose, $\mathrm{pH}$, contact time, and adsorbent particle size, to reach the optimized conditions (maximum adsorption). The adsorption of $\mathrm{Pb}(\Pi)$ on (P.a) involved fast and slow process as a mechanism steps according to obey two theoretical adsorption isotherms; Langmuir and Freundlich. The thermos dynamic adsorption parameters were evaluated also. The $(\Delta \mathrm{H})$ obtained positive value that meanes adsorption of lead ions was an endothermic processwhile $(\Delta G)$ values were negative which means that adsorption of lead ions was a spontaneous process and the decrease in $(\Delta G)$ with temperature increasing revealed that lead ions adsorption on (P.a) became favorable with temperature increasing.
\end{abstract}

Key words: Adsorption, PhragmitesAustralis, Lead ions, percentage removal.

\section{Introduction:}

Phragmitesaustralis (P.a) was widely used in the last two decades for industrial water treatment to adsorbed metallic ions[1]. The toxic ions and molecules such as heavy metals and other pollutants released into the ground water and surface as results of different industrial activities, agriculture and mining [2]. The possible gender of lead ions to the ecosystem through the soil, water, and air perform to necessity removing of $\mathrm{Pb}(\Pi)$.Lead ions (Inorganic form) causes a disturbance in central of the nervous system by chang the characteristics of the early organism[3].The pathway for entry of metals in to the environment was particularly industrial waste water in electroplating, metal industrial finishing, tannery process, chemical manufacturing and battery manufacturing industries[4]. In drinking 
water there must be the maximum permissible limit(MPL) of lead is about 0.05 ppm[5].Many methods like chemical precipitations, adsorption and convention [6-11], ion exchange[12],methods of membrane separation[13] and electro-remediation ways[14] available for waste water treatment. Most methods are economically feasible, costly and not eco-friendly and led to secondary effluent impact on the environment. Most of these methods are not efficient to remove low concentrations of the heavy metal ions and mostly very expensive, so asimple effective, ecofriendly and low-cost methods are required to reach fine tuning of polluted waste water. The study for easily available adsorbents with low cost has led to the investigation of agricultural and biological origin materials. Such low cost adsorbents us example are clay[15],cotton by-products [16], wool by-products[17], tea leaves [18] and some other materials [19-21]. Natural materials can potentially by modified using variety of chemical/physical treatment to achieve the desired surface properties for best immobilization performance of specific compounds [22]. When the surfaces are modified used introducing long organic chain compounds like Sodium Dodecyl Sulfate (SDS), high sorption of pollutants can be achieved [23].The study reported here aimed the ability of seed, Phragmitesaustralis (P.a) (Iraqi plant) to uptake lead ions and study the effect of modification of (P.a) by (SDS) on the enhancement of percentage lead removal from aqueous solutions at different $\mathrm{pH}$ and temperatures.

\section{Materials and Methods:}

Iraqi environment seed, Phragmites australis (P.a) were collected,washed,dried then grind to a powder and conserved in desiccators. $\mathrm{SDS}\left[\mathrm{CH}_{3}\left(\mathrm{CH}_{2}\right)_{11} \mathrm{OSO}_{3} \mathrm{Na}\right]$
$\mathrm{C}_{12} \mathrm{H}_{25} \mathrm{NaO}_{4} \mathrm{~S}$ with M.wt.= 288.38 g.mol ${ }^{-1}$ were supplied from Fluka with purity $99.9 \%$ were used to modified Iraqi seed, $\mathrm{HCl} 36 \%, \mathrm{NaOH} 99.9 \%$ also supplied from Fluka were used to adjust $\mathrm{pH}$ of the solutions. A stock solution of lead ions (1000 ppm) were prepared from $1 \mathrm{~g}$ of $\left[\left(\mathrm{CH}_{3} \mathrm{COO}\right)_{2} \mathrm{~Pb} .3 \mathrm{H}_{2} \mathrm{O}\right]$ with purity reach $99.9 \%$ supplied from Riedel- Dehaenag dissolved in $1 \mathrm{~L}$ distilled water, different solutions concentration were prepared by dilution. Atomic Absorption Spectrometer method was used to follow lead ion concentration before and after adsorption process. The (AAA) apparatus type GBC 933 plus, Australian origin where used in this study. Two types of adsorbents, P.a. and modified P.a by SDS were used to study the percentage removal of lead from synthesized waste water. The modified P.a/ SDS was prepared by adding $0.2 \mathrm{~g}$ SDS to $10 \mathrm{~g}$ seed with $250 \mathrm{ml}$ distilled water; this mixture left for $24 \mathrm{~h}$ with stirring then filtered washed then the modified P.a dried in $100^{\circ} \mathrm{C}$ furnace.

\section{Experiments Part (Experiments of Batch Adsorption)}

Batch Adsorption experiments performed by adding the amount of the stock solution $250 \mathrm{ml}$ in a volumetric flask at the designated adsorbent dose, $\mathrm{pH}$, and temperature. The solution was shaken using a mechanical shaker (Griffin and George LTD.), Britain origin a definite period of $250 \mathrm{rpm}$ for adsorbent dose, temperature, contacttime, and $\mathrm{pH}$ were optimized by variation continuous method (studying one, keeping other data constant). After equilibrium rating, the system allowed settle for 20-30 min, filtered and determined lead. The difference in the lead content before and after adsorption experiments represents the amount of lead absorbed by the P.a or $\mathrm{Pa} / \mathrm{SDS}$ adsorbent. The $\mathrm{P} \%$ of $\mathrm{Pb}^{+2}$ can calculate using this equation [24]: 
Percent removal $(\% \mathrm{R})=[(\mathrm{Co}-\mathrm{Ce}) / \mathrm{Co}] *$ $100 \ldots . . . . . . .1$

Where, $\mathrm{Co}=$ initial $\mathrm{Pb}^{+2}$ concentration (ppm), $\mathrm{Ce}=$ final $\mathrm{Pb}^{+2}$ concentration in the solution (ppm).

\section{Results and Discussion:}

\section{The effect of adsorbent dose}

Fig. 1. Shows the variation of $\% \mathrm{R}$ with adsorbent dose $(\mathrm{g})$ for $40 \mathrm{ppm} \mathrm{Pb}^{2+}$ at $298 \mathrm{~K}$ at $\mathrm{pH} 6$.

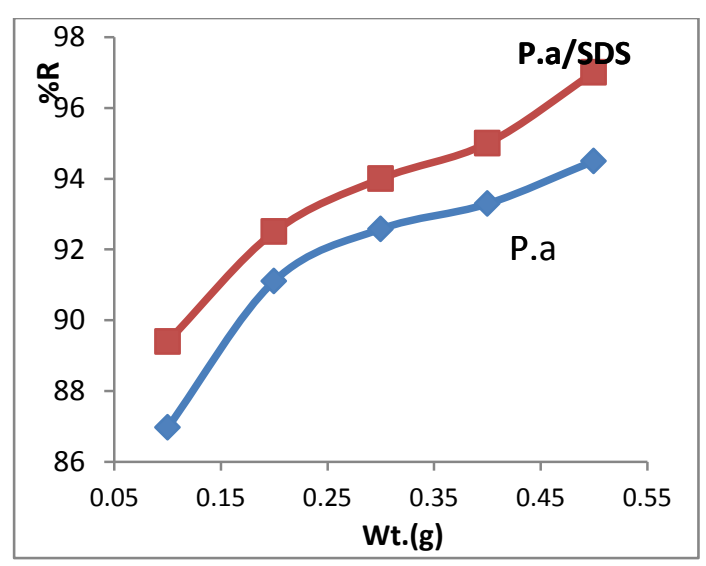

Fig. 1: Variation of $\% \mathrm{R}$ with different adsorbent dose (a) P.a/ adsorbent;(b) $\mathrm{Pa} / \mathrm{SDS}$ adsorbent at $298 \mathrm{~K}, \mathrm{C}_{0}=$ 40ppm.

\section{2: The effect of $\mathrm{pH}$ :}

pH plays an important role in adsorption mechanisms. Fig. 2 shows the variation of $\% \mathrm{R}$ of $\mathrm{Pb}^{2+}$ with $\mathrm{pH}$ by P.a and P.a /SDS adsorbent at $298 \mathrm{~K}$ with $20 \mathrm{ppm}$ $\mathrm{Pb}^{2+}$ solution.

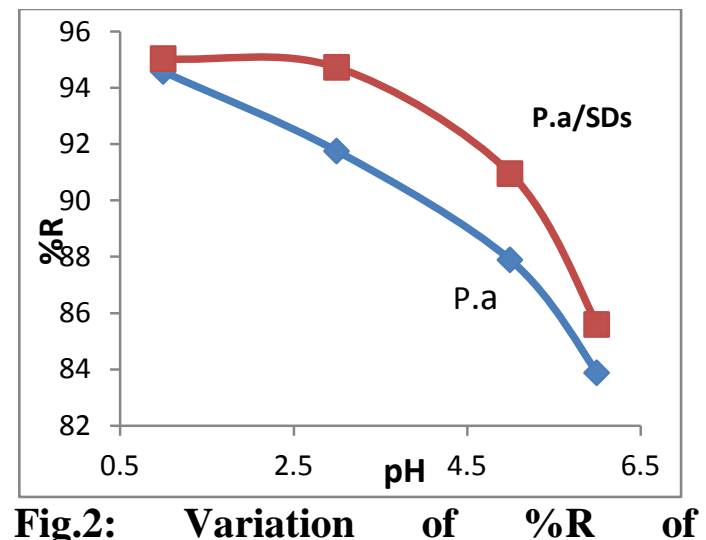

$\mathrm{Pb}^{2+}$ withpH by (a)P.a; (b) P.a/SDS at $298 \mathrm{~K}$ and $\mathrm{C}_{0}=20 \mathrm{ppm}$.

\section{The effect of contact time}

The adsorption of $\mathrm{Pb}^{2+}$ by the two adsorbent was carried out by shaking the aqueous suspensions for a different time to evaluated the equilibrium time, which was (80 min.) for P.a and P.a /SDS as shown in Fig.3.

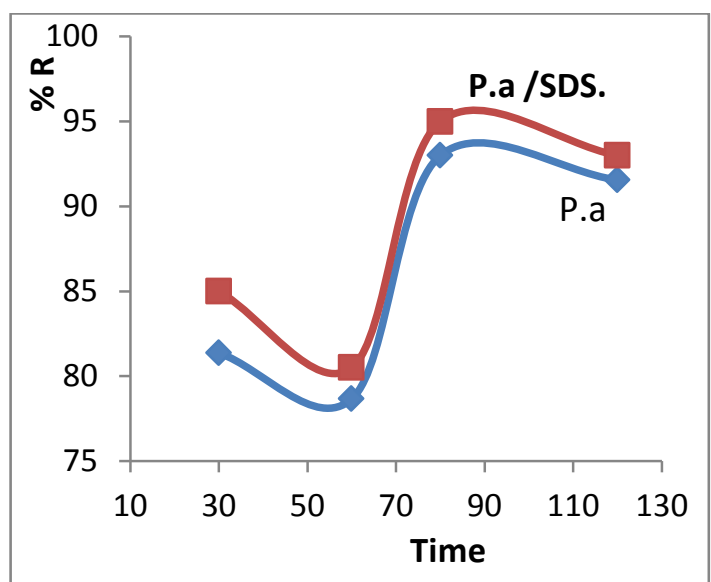

Fig.3: The Variation of $\% \mathrm{R}$ with time for (a) P.a,: (b) P.a /SDS adsorbent at $298 \mathrm{~K}$ and $\mathrm{Co}=20 \mathrm{ppm}$.

The adsorbed amount of both adsorbent (mg . $\mathrm{g}^{-1}$ ) were calculated as follows[25]: $\mathrm{q}_{\mathrm{e}}=\left(\mathrm{C}_{\mathrm{o}}-\mathrm{C}_{\mathrm{e}}\right) \mathrm{V} / \mathrm{w} \ldots \ldots \ldots \ldots .2$

Where $\mathrm{C}_{\mathrm{o}}$ and $\mathrm{C}_{\mathrm{e}}$ the initial concentrations, and final $\mathrm{Pb}^{+2}$ concentrations ( $\mathrm{ppm}$.), respectively, $\mathrm{V}$ is the volume of $\mathrm{Pb}^{+2}$ solutions( $\mathrm{L}$ ) and (w) is the mass of adsorbent (p.a) or P.a /SDS(gm.).

\section{Analysis of equilibrium data.}

Freundlich and Langmuir adsorption isotherms were applied forthe $\mathrm{Pb}^{2+}$ adsorption, and the experimental data was fitted. The best model which was fitted according to statistical criteria $\left(\mathrm{R}^{2}\right)$ correlation or regression coefficient. The adsorption isotherm name Langmuir was derived supposing that the $\mathrm{Pb}^{2+}$ adsorption was take place on homogenous monolayer with adsorption sites of equal energy,this layer coverage can be described as[26].

$\mathrm{q}_{\mathrm{e}}=\mathrm{q}_{\mathrm{m}}[\mathrm{bCe} / 1+\mathrm{bCe}]$ 3 
Where $\mathrm{qe} / \mathrm{mg} \mathrm{g}^{-1}$ and $\mathrm{Ce} / \mathrm{mg} \cdot \mathrm{L}^{-1}$, are equilibrium concentration on adsorbent surface and adsorbate concentration in the solution ,respectively $b$ is a constant related to the equilibrium constant, which represents the affinity between $\mathrm{Pb}^{2+}$ and the surface, $\mathrm{q}_{\mathrm{m}} / \mathrm{mg}^{-1}$ is the maximum quantity adsorbed by the surface. The empirical Freundlich isothermic model can represent in following equation [27].
$\mathrm{q}_{\mathrm{e}}=\mathrm{kCe}^{1 / \mathrm{n}}$ . .4

In this model the adsorption amount was increased indefinitely with the concentration of $\mathrm{Pb}^{2+}$ in the solution Freundlich isotherm holds was for heterogeneous surface where the adsorption energy sites were not similar Fig.4: Shows the Langmuir isotherm on (P.a) and (P.a/SDS) at different temperatures.
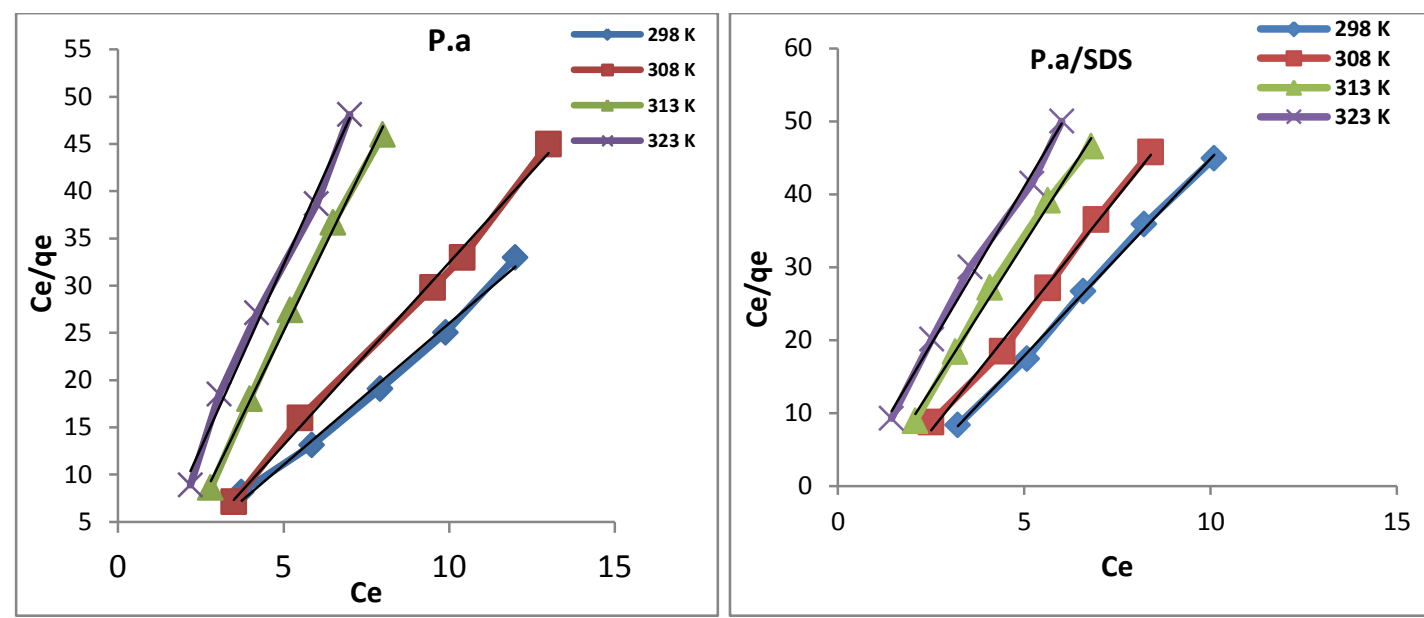

Fig.4: Langmuir isotherm for (a) -(P.a),(b) -(P.a/SDS) at different temperatures.

While Fig.5: Shows the Freundlich isotherm on the two adsorbents.
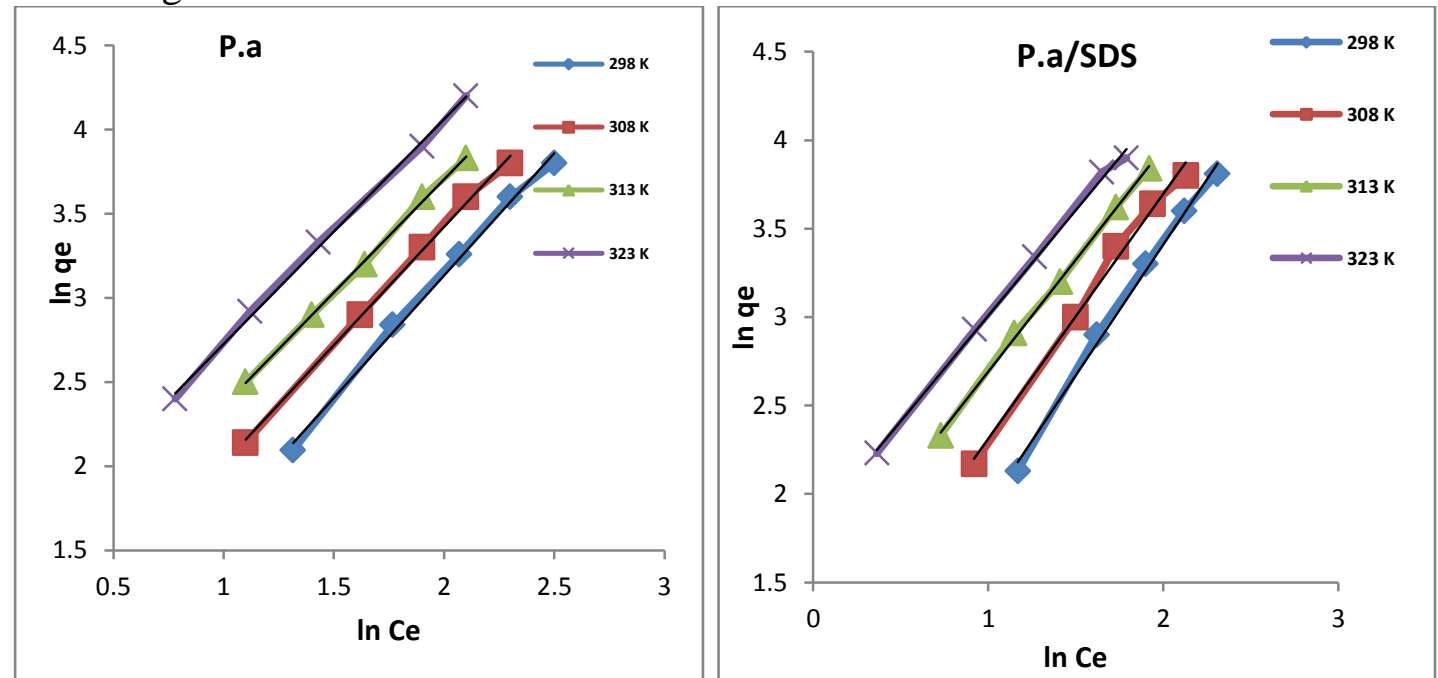

Fig.5: Freundlich isotherm on (a)-(P.a),(b) $-($ P.a/SDS) at different temperatures.

Parameters were listed in Table 1, where $\mathrm{R}^{2}$ for Freundlich model are higher in values than for Langmuir $R^{2}$ values, that means the former model is more applicable than the later. 
Table (1): Represented the data of the above two model.

\begin{tabular}{|c|c|c|c|c|c|c|c|c|c|c|c|c|}
\hline \multicolumn{7}{|c|}{ Langmuir } & \multicolumn{6}{|c|}{ Freundlich } \\
\hline \multicolumn{3}{|l|}{$\mathrm{k}_{\mathrm{L}}$} & \multicolumn{2}{|l|}{$\mathrm{a}$} & \multicolumn{2}{|l|}{$\mathrm{R}^{2}$} & \multicolumn{2}{|l|}{$\mathrm{K}_{\mathrm{F}}$} & \multicolumn{2}{|r|}{$\mathrm{n}$} & \multicolumn{2}{|l|}{$\mathrm{R}^{2}$} \\
\hline $\mathrm{T} / \mathrm{K}$ & P.a & P.a/SDS & P.a & P.a/SDS & P.a & P.a/SDS & P.a & P.a/SDS & P.a & P.a/SDS & P.a & P.a/SDS \\
\hline 298 & 1.981 & 2.040 & 0.438 & 0.059 & 0.842 & 0.965 & 1.256 & 1.562 & 0.688 & 0.675 & 0.995 & 0.994 \\
\hline 308 & 2.557 & 3.077 & 0.049 & 0.055 & 0.879 & 0.93 & 1.840 & 1.154 & 0.711 & 0.391 & 0.997 & 0.909 \\
\hline 318 & 3.358 & 5.494 & 0.054 & 0.093 & 0.963 & 0.868 & 1.647 & 3.939 & 0.613 & 0.785 & 0.967 & 0.981 \\
\hline 323 & 4.549 & 6.452 & 0.027 & 0.035 & 0.964 & 0.670 & 2.792 & 3.235 & 0.974 & 0.550 & 0.966 & 0.984 \\
\hline
\end{tabular}

\section{The effect of Temperature.}

The adsorption extent of $\mathrm{Pb}^{2+}$ on (P.a) and (P.a/SDS) at different temperatures are shown in Fig.6. the increasing in temperature cause to enhance the adsorption percentage $\% \mathrm{R}$ of $\mathrm{Pb}^{2+}$ because of increasing the mobility and diffusion of ionic species. Where diffusion process is an endothermic

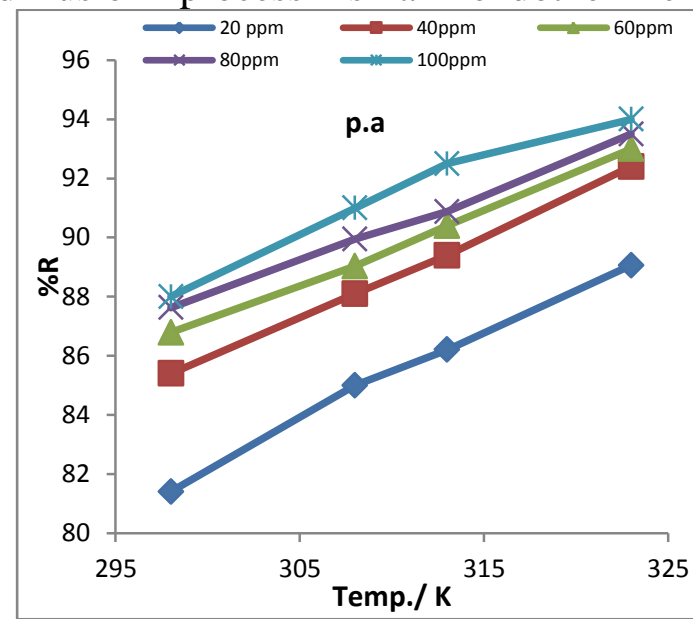

process, so the increasing in $\% \mathrm{R}$ was expected. Also, the increasing in temperature led enlargement of pore size according to activated diffusion and micropores be wider and more pores were created than adsorption as enhanced.[28].

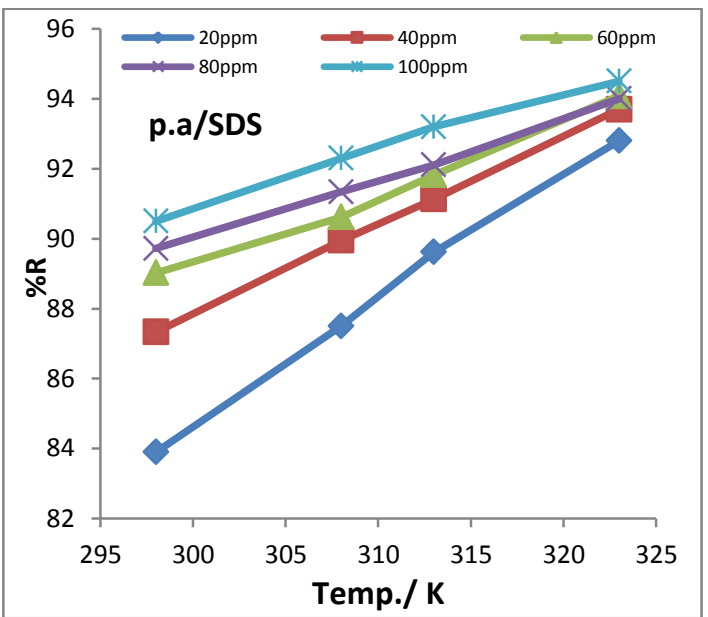

Fig.6:Variation of $\% \mathrm{R}$ of $\mathrm{Pb}^{2+} \mathrm{by}$ (a)-(P.a), (b) - (P.a/SDS) surfaces with temperature for different $\mathrm{Pb}^{2+}$ concentration.

6. Calculation of Thermodynamic Parameters:

The parameters of Thermodynamic Entropy and Enthalpy $(\Delta \mathrm{S} \& \Delta \mathrm{H})$ values for adsorption process were calculated from the slope and intercept of linear Vant Hoff plot, respectively using the following relation [28]:

$$
\ln k_{d}=\frac{\Delta S}{R}-\frac{\Delta H}{R T} \cdot \ldots \ldots \ldots \ldots
$$

Where $\Delta \mathrm{S}$ is the entropy change for the process, $\Delta$ His the enthalpy change for the adsorption process, $\mathrm{R}$ is the gas constant and $\mathrm{T}$ is the absolute temperature.

The distribution coefficient $\left(\mathrm{k}_{\mathrm{d}}\right) /$ $\mathrm{mL} / \mathrm{gon}$ (P.a) and (P.a/SDS) surfaces were calculated using the following equation [29]:

$\mathrm{k}_{\mathrm{d}}=\left(\mathrm{C}_{\mathrm{o}}-\mathrm{C}_{\mathrm{e}} / \mathrm{C}_{\mathrm{e}}\right) \times(\mathrm{V} / \mathrm{m})$

The change in free energy $\Delta G$ for the specific adsorption process have also been calculated using the following equation [30]:

$\Delta \mathrm{G}=$ - RT $\operatorname{lnk}_{\mathrm{d}} \ldots \ldots \ldots \ldots \ldots \ldots . .7$

Fig. 7 shows the linear relation between link and reciprocal of temperature, $\Delta H$ and $\Delta \mathrm{S}$ values were calculated from the slope and intercept of linear Fig.7 relation respectively, all thermodynamics data were represented in Table 2. 
Table2. The adsorption thermodynamic parameter for different $\mathrm{Pb}^{2+}$ concentration on $P$.a and $P$.a/SDS at different temperatures.

\begin{tabular}{|c|c|c|c|c|c|c|c|c|c|c|c|}
\hline $\mathrm{C}_{\mathrm{o}}$ & & & & P.a & & & & & P.a/SDS & & \\
\hline PPm. & $(1 / \mathrm{T}) 10^{-3}$ & $\begin{array}{c}\mathrm{Kd} \\
(\mathrm{mgL} \cdot \mathrm{g}- \\
1 \\
\end{array}$ & $\operatorname{lnKd}$ & $\begin{array}{c}-\Delta \mathrm{G} \\
(\mathrm{KJ} / \mathrm{mol})\end{array}$ & $\begin{array}{c}\Delta \mathrm{H} \\
\mathrm{KJ} / \mathrm{mol})\end{array}$ & $\begin{array}{c}\Delta \mathrm{S} \\
\mathrm{J} / \mathrm{K} \cdot \mathrm{mol}\end{array}$ & $\begin{array}{c}\mathrm{K}_{\mathrm{d}} \\
(\mathrm{mgL} \cdot \mathrm{g}- \\
1 \mathrm{f})\end{array}$ & $\ln K_{d}$ & $\begin{array}{c}-\Delta \mathrm{G} \\
\mathrm{KJ} / \mathrm{mol})\end{array}$ & $\begin{array}{c}\Delta \mathrm{H} \\
\mathrm{KJ} / \mathrm{mol})\end{array}$ & $\begin{array}{c}\Delta \mathrm{S} \\
\mathrm{J} / \mathrm{K} \cdot \mathrm{mol}\end{array}$ \\
\hline \multirow{4}{*}{20} & 3.356 & 2.184 & 0.781 & 1.935 & \multirow{4}{*}{80.514} & \multirow{4}{*}{287.780} & 0.957 & 0.957 & 2.370 & \multirow{4}{*}{50.089} & \multirow{4}{*}{186.620} \\
\hline & 3.250 & 7.833 & 0.998 & 5.184 & & & 3.500 & 1.253 & 3.208 & & \\
\hline & 3.145 & 6.143 & 1.215 & 4.812 & & & 8.633 & 2.156 & 5.700 & & \\
\hline & 3.048 & 4.070 & 1.404 & 3.829 & & & 6.444 & 1.863 & 5.080 & & \\
\hline \multirow{4}{*}{40} & 3.356 & 2.914 & 1.071 & 2.653 & \multirow{4}{*}{40.170} & \multirow{4}{*}{154.840} & 3.140 & 1.140 & 2.824 & \multirow{4}{*}{46.719} & \multirow{4}{*}{182.070} \\
\hline & 3.250 & 3.476 & 1.300 & 3.190 & & & 4.025 & 1.392 & 3.570 & & \\
\hline & 3.145 & 4.522 & 1.509 & 3.990 & & & 5.850 & 1.766 & 4.670 & & \\
\hline & 3.048 & 6.047 & 1.799 & 4.907 & & & 7.496 & 2.015 & 5.494 & & \\
\hline \multirow{4}{*}{60} & 3.356 & 3.287 & 1.190 & 2.958 & \multirow{4}{*}{38.869} & \multirow{4}{*}{153.580} & 4.052 & 1.340 & 3.320 & \multirow{4}{*}{39.371} & \multirow{4}{*}{157.750} \\
\hline & 3.250 & 4.059 & 1.400 & 3.528 & & & 4.830 & 1.575 & 4.080 & & \\
\hline & 3.145 & 5.303 & 1.670 & 4.415 & & & 6.167 & 1.819 & 4.810 & & \\
\hline & 3.048 & 6.643 & 1.894 & 5.165 & & & 7.951 & 2.074 & 5.660 & & \\
\hline \multirow{4}{*}{80} & 3.356 & 3.666 & 1.264 & 3.221 & \multirow{4}{*}{25.274} & \multirow{4}{*}{104.209} & 4.366 & 1.474 & 3.652 & \multirow{4}{*}{41.664} & \multirow{4}{*}{168.361} \\
\hline & 3.250 & 4.500 & 1.004 & 3.789 & & & 5.270 & 1.662 & 4.251 & & \\
\hline & 3.145 & 5.750 & 1.730 & 4.574 & & & 6.593 & 1.890 & 4.990 & & \\
\hline & 3.048 & 5.812 & 1.990 & 4.7995 & & & 8.111 & 2.094 & 5.710 & & \\
\hline \multirow{4}{*}{100} & 3.356 & 3.350 & 1.264 & 3.132 & \multirow{4}{*}{25.274} & \multirow{4}{*}{110.290} & 8.900 & 2.186 & 5.416 & \multirow{4}{*}{48.155} & \multirow{4}{*}{185.727} \\
\hline & 3.250 & 4.475 & 1.498 & 3.836 & & & 5.750 & 1.749 & 4.480 & & \\
\hline & 3.145 & 5.650 & 1.730 & 4.574 & & & 6.853 & 1.925 & 5.010 & & \\
\hline & 3.048 & 5.607 & 1.724 & 4.701 & & & 8.272 & 2.113 & 5.762 & & \\
\hline
\end{tabular}

The positive $\Delta \mathrm{H}$ values mean that the adsorption process was endothermic while negative $\Delta \mathrm{G}$ values which are increase with temperature reveals that adsorption of $\mathrm{Pb}^{2+}$ on the two adsorbent becomes more favorable at a higher temperature. Positive $\Delta \mathrm{S}$ values mean that the increasing in randomness at solid solution interface during the fraction of $\mathrm{Pb}^{2+}$ on the active site of the adsorbentwas occurred.
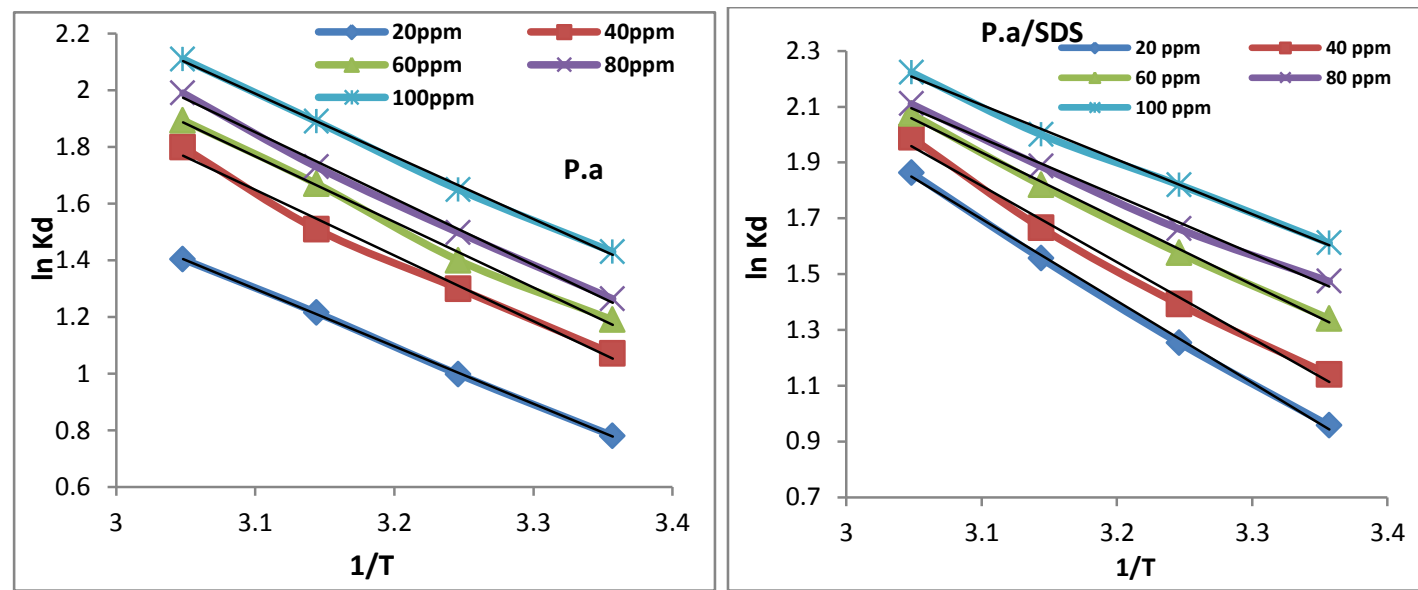

Fig.7:Plot of $\ln K_{d}$ vs. 1/T (pH=6 at different $\mathrm{Pb}^{2+}$ conc.) on (a) (P.a),(b) (P.a/SDS) adsorbent.

\section{Order of $\mathrm{Pb}^{2+}$ adsorption reaction.}

The rate constant $(\mathrm{k})$ of $\mathrm{Pb}^{2+}$ adsorption at the two adsorbent surfaces was calculated at $298 \mathrm{~K}$ keeping the equilibrium time $(80 \mathrm{~min}$.) using the following equation[30]:

$$
k=\frac{1}{t} \ln \frac{C_{o}}{C_{e}} \ldots \ldots \ldots \ldots . . . .8
$$

Where $\mathrm{C}_{0}, \mathrm{C}_{\mathrm{e}}$ are the initial and equilibrium $\mathrm{Pb}^{2+}$ concentration respectively. The values of $\mathrm{C}_{\mathrm{e}}$ and $\mathrm{k}$ for adsorption process at different $\mathrm{C}_{\mathrm{o}}$ concentrations of $\mathrm{Pb}^{2+}$ are calculated. Fig.8 shows a first order kinetics reaction between rate constant and $\ln$ $\mathrm{C}_{0} / \mathrm{C}_{\mathrm{e}}$ where a linear relation was obtained. The rate constant values for the adsorption of $\mathrm{Pb}^{2+}$ on (a) (P.a), (b) (P.a/SDS) after (80 min) was listed in table 3. 

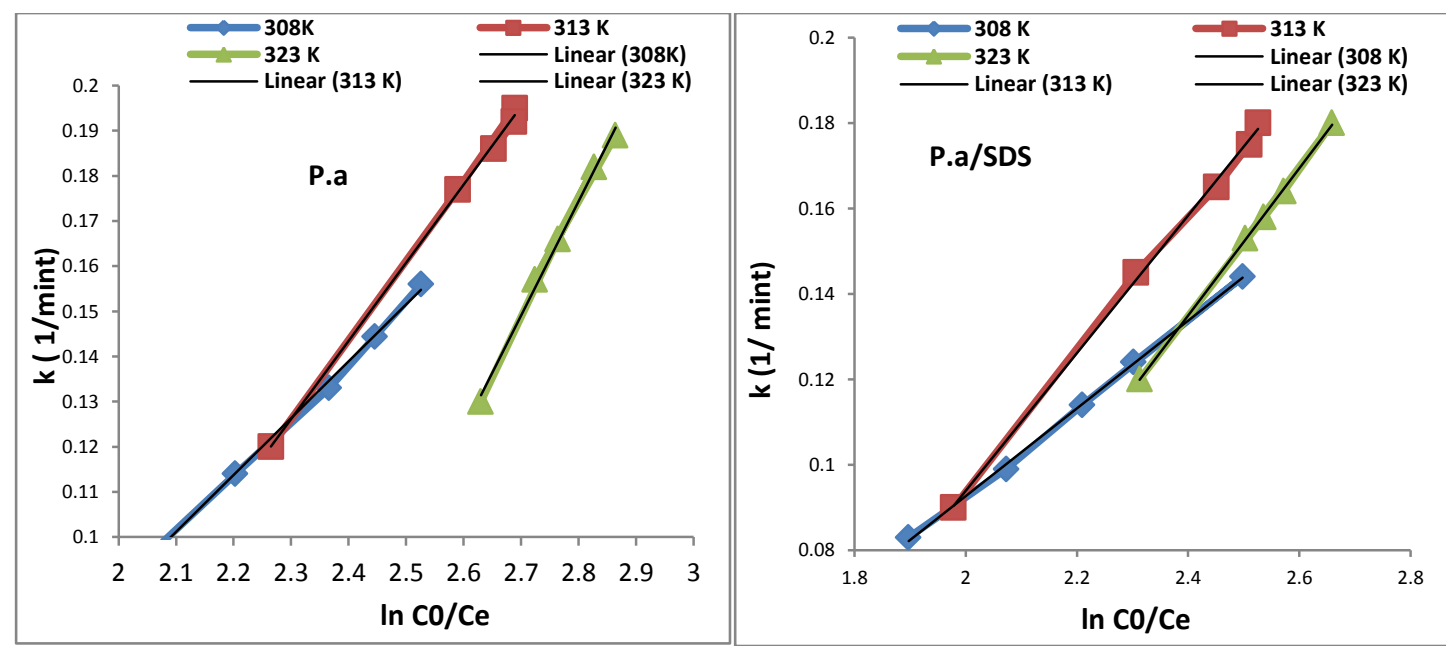

Fig.8:Plot of rate constant $k$ for adsorption process against $\ln _{0} / C_{e}$ on (a)(P.a),(b) (P.a/SDS) adsorbent.

Table 3.The rate constant values for the adsorption of $\mathrm{Pb}^{2+}$ on P.a and P.a/SDS.

\begin{tabular}{|c|c|c|c|c|c|c|c|}
\hline \multicolumn{4}{|c|}{ P.a } & \multicolumn{4}{|c|}{ P.a/SDS } \\
\hline $\mathbf{T} / \mathbf{K}$ & $\mathrm{C}_{0} / \mathrm{ppm}$ & $\ln C_{0} / C_{e}$ & $\mathrm{k} / \mathrm{mint}^{-1}$ & $\mathbf{T} / \mathbf{K}$ & $\mathrm{C}_{0} / \mathrm{ppm}$ & $\ln C_{0} / C_{e}$ & $\mathrm{k} /$ mint $^{-1}$ \\
\hline \multirow{5}{*}{308} & 20 & 1.897 & 0.083 & \multirow{5}{*}{308} & 20 & 2.078 & 0.099 \\
\hline & 40 & 2.073 & 0.099 & & 40 & 2.203 & 0.114 \\
\hline & 60 & 2.210 & 0.114 & & 60 & 2.366 & 0.133 \\
\hline & 80 & 2.498 & 0.124 & & 80 & 2.446 & 0.177 \\
\hline & 100 & 2.302 & 0.125 & & 100 & 2.525 & 0.156 \\
\hline \multirow{5}{*}{313} & 20 & 1.978 & 0.090 & \multirow{5}{*}{313} & 20 & 2.265 & 0.120 \\
\hline & 40 & 2.306 & 0.125 & & 40 & 2.590 & 0.166 \\
\hline & 60 & 2.451 & 0.145 & & 60 & 2.689 & 0.123 \\
\hline & 80 & 2.510 & 0.154 & & 80 & 2.652 & 0.245 \\
\hline & 100 & 2.526 & 0.156 & & 100 & 2.688 & 0.184 \\
\hline \multirow{5}{*}{323} & 20 & 2.313 & 0.114 & \multirow{5}{*}{323} & 20 & 2.630 & 0.173 \\
\hline & 40 & 2.572 & 0.164 & & 40 & 2.764 & 0.198 \\
\hline & 60 & 2.659 & 0.174 & & 60 & 2.827 & 0.297 \\
\hline & 80 & 2.503 & 0.153 & & 80 & 2.724 & 0.282 \\
\hline & 100 & 2.536 & 0.158 & & 100 & 2.864 & 0.219 \\
\hline
\end{tabular}

Rate constant values of adsorption on (P.a/SDS) was higher than on (P.a) surface, So SDS enhance the $\% \mathrm{R}$ and the velocity of the adsorption process.

\section{Conclusion:}

The Laboratory batch experiments revealed that modification Phragmitesaustralis (P.a)by SDS lead to increase the rate of adsorption process and increase the $\mathrm{Pb}^{2+}$ percentage removal. Adsorption of $\mathrm{Pb}^{2+}$ on P.a and P.a / SDS followed first order reaction of Freundlich isotherm type. The obtained thermodynamic calculation indicate an endothermic adsorption process for the adsorption process on P.a and P.a /SDS, and SDS lead to increase the $\Delta \mathrm{G}$ values in general which means, adding SDS lead to increase the thermodynamic feasibility of adsorption where SDS molecules act as a center of adsorption sites, these sites make adsorption process more random as $\Delta \mathrm{S}$ positive values was generally higher in case of adding SDS for (P.a).

\section{References:}

[1] YE, Z. H.; Baker, A. S. M.; Wong, M. H. and Willis, A.J., 1997. Zinc, lead and Cadmium Tolerance Uptake and accumulation the common Reed, Phragmitesaustralis(Cav.0Trin.ExSte udel.,Annals of Botany,80(12): 363370. 
[2]Bounheny, S.; Kazunori, N.; Munehiro, N.; Nobou,C. and Osamu,N. 2006.Purification with activated carbon,WaterRes., 40(22):2295.

[3] Johnson, F. M. 1998. The genetic effects of environmentallead, Mutat. Res-Rev. Mulat. Res., 410(30):123.

[4] Who Guideline values for Drinkingwater Quality, 1984. Recommendations, world Health Organization; Geneva; 1(2): 81.

[5] Singanan, M. 2003.The International Conference, On Water, and environmentBhopal, India; 45-49.

[6]Maity, S.; Chakravarthy, K. and Bhattacharjee, K. S. 2003. Proceeding of the conference on water and Environment (WE-2003), Bhopal,India,; 324-331.

[7] Amriphale, S. S.; Prased, M.; Sexena, S. and Chandra N. 1999. Separation of trace antimony and arsenic prior to hydride generation atomic absorption spectrometric determination, Met. Chem, n. 22(12): 557.

[8] Rao, M. M.; Rao, G. P. C.; Seshaiah, K. N.; Choudary, V. and Wang, M. C. 2007. Activated carbon from Ceibapetandra hulls, an agricultural waste, as an adsorbent in the removal of $\mathrm{Pb}$ (II) and zinc from aqueoussolutions. Waste Manage., 28(5): 849-858.

[9]Chandra, N.; Agnihotri, N.; Sanjeev, B. and Amritphal, S. S. 2003. Procceding of the International conference on water and Environment (WE-2003), Bhopal, India, pp 125-130.

[10] Aktar, S.; Qadeer, R. 1997. Kinetics Study of Lead ion Adsorption on Active Carbon, Adsorp. Sci. Technol,15(9):815.

[11] Singanan, M.; Abebaw, A. and Vinodhimi, S. 2005. Removal of lead ions fromindustrial wastewater By using Biomaterials, Bull. Chem. Ethiop. 19(2):189-294.
[12] Mier, M. V.; Callejas, R. R.; Gehr, R.; Cisneros, B. and Alvarez, P. J. J. 2001. Lead Ion removal from industrial effluent by using water. Res., 35(8):373.

[13] Reddod, Z.; Gerente, C.; Andeers, Y.; Pierre, Le. 2002. Adsorption of several metal ions ontolowcostbiosorbent: kinetic and equilibriumstudies., Environ. Sci. Technal, 1;36(9):2067-73.

[14] Zhongming, L. I. and Wele, X. J. 1998. Environment and its protection byscientific, Environ. Sci. Technol. 32(12):394.

[15] Farrah, H. and Pickering, W. F. 1977. Removal of heavy metals from paint industry's wastewater using Leca as an available adsorbent Ans. J. Chem., 30, 1417.

[16] Robert, J. E. and Rowland, P. S. 1973. Removalof metal ion from aqueous Solution by Adsorption, environ. Sci. technol.7(9):552.

[17]Balko's, D. and Balatocioglu, H. 1992. Lab. and Life Sciences Equipment New to Inventory, J. Chem. Technol. Biotechnol. 54(10):393.

[18] Tee, T. W. and Khan, A. R. M. 1988. Removal of lead, cadmium and zinc by waste tea leaves. Environ TechnolLett. 9(11): 1223-1232.

[19] Prasad, M. N. V. and Freitas, H. 2000. Removal of toxic metals from solution by leaf, stem and root phytomass of Quercus ilex L. (hollyoak), Enveron. Pollut. 110(36):277-283.

[20] Babel, S. and Kurniawan, T. A. 2003. Low-cost adsorbents for heavy metals uptake from contaminated water,J. Hazard Mater, B.97(30):219 $-43$.

[21] Drake, L. R. and Rayson, G. D. 1996. Chemical heterogeneity of binding sites is an inherent characteristic, Anal. chem. 68(34): 22A-27A. 
[22] Sheng, P. X.; Ting, Y. P.; Chen, J. P. and Hong, L. 2004. Metals Removal to Low Levels Using Chemical Precipitants, J. Colloid interface Sci. 275(40): 131.

[23] Boyd, S. A.; Shoba, S.; Lee, J. F. and Mortland, M. M. 1988. Pentachlorophenol Sorption by Organo-Clays,clays and clay minerals. 36(9):125-130.

[24] Badmus, M. A. O.; Audu, T. O. K. and Anyata, B. 2007. Removal of lead Ion from Industrial wastewater by Activated carbon prepared from periwinkleshells(Typanotonusfuscatu s)", Turkish. Eng. Env. Sci. 31(11):251-263.

[25] AL-Saadie, K. A. and Jassim, S. B. 2010. Adsorption study for Chromium (vI)on Iraqi Bentonite, Baghdad Science Journal.7(1):(745756).

[26]Kostelnikova, H.; Praus, P. and Turicova, M. 2008. Adsorption of
Phenol and Aniline by original and quaternary ammonium salts-modified montmorillonite.ActaGeodyn.Gem later. 5 (19): 83-88.

[27]Mengrsitic, A. A.; SivaRao, T.; VprasadaRao, A. and Singanan, M. 2008. Removal of Lead (П)Ions from Aqueous solutions using Activated Carbon from Militia ferrginea plant Leaves, Bull. Che. Sec. Ethiop, 22(3):349-360.

[28]Stephen, I. B. and Sulochana, N. 2003. Proceeding of aninternational conference on water and Environment (WE-2003), Bhopal, India, 22-28.

[29]Waranusantigul, P.; Pokethityook, P.; Krnatra, M.andchne, E. S. 2003. Environ. pollut. 1(1): pp.20-23.

[30] Raj, G. 2001. Chemical kinetics in Advanced physical Chemistry, 4thed. Geol Puplishing House; Meerut, India, pp.669-676 and 149-150.

\section{ازالة ايونات الرصاص الثنائية من المحاليل المائية باستعمال نبات القصب العراقي}

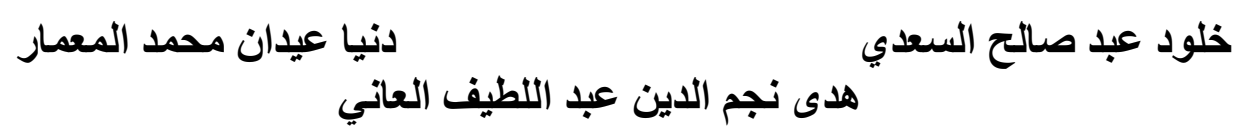

قسم الكيمياء، كلية العلوم، جامعة بغداد، بغداد، العراق

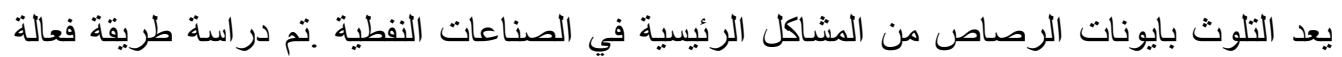

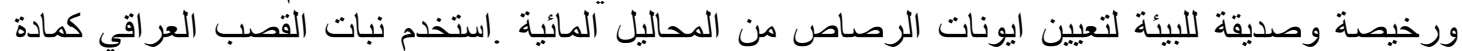

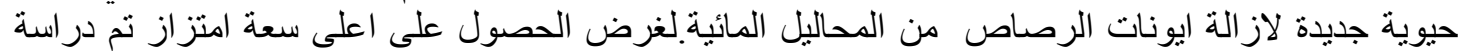

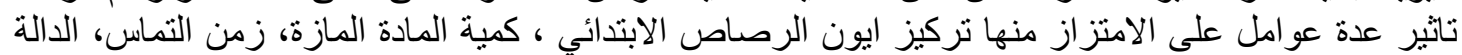

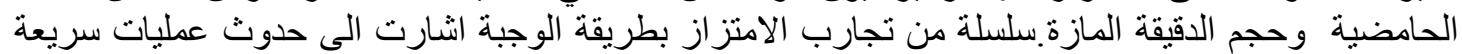

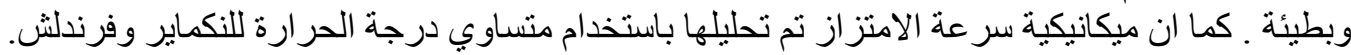

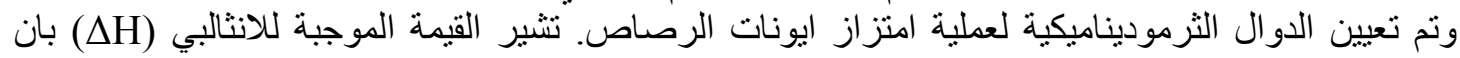

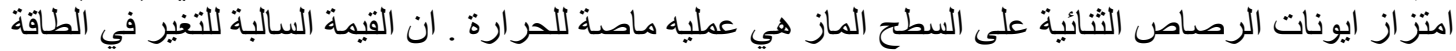

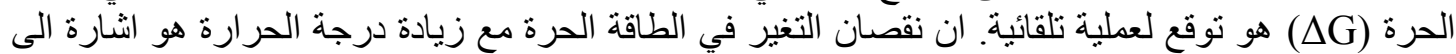
ان امنز از ايونات الرصاص على لعلى سطح المادة المازة هي مفضلة في درجات الفيلة الحر ارة العالية. الكلمات المفتاحية :الامتزاز، نبات القصب، ايونات الرصاص، النسبه المئوية للاز الة. 